\title{
WPŁYW CZYNNIKÓW SPOŁECZNO-EKONOMICZNYCH KLIENTÓW NA POZIOM KORZYSTANIA Z PRODUKTÓW I USŁUG BANKOWOŚCI ELEKTRONICZNEJ
}

\author{
Edward Czarnecki \\ Katedra Finansów \\ Szkoła Główna Gospodarstwa Wiejskiego w Warszawie
}

\begin{abstract}
Abstrakt. Celem pracy jest określenie wpływu czynników społeczno-ekonomicznych klientów (wiek, miejsce zamieszkania, wykształcenie, aktywność zawodowa, poziom dochodów, poziom kompetencji informatycznych) na korzystanie z produktów i usług bankowości elektronicznej. Praca składa się z dwóch części. W pierwszej przedstawiono wyniki wcześniejszych badań dotyczących zagadnień korzystania klientów banków z produktów i usług świadczonych drogą elektroniczną. W drugiej części przedstawiono opis badań własnych oraz ich wyniki. Wpływ czynników demograficznych na poziom korzystania określono za pomocą testu chi-kwadrat. Wyniki badań wskazują, że tylko wiedza i umiejętności informatyczne respondentów mają wpływ na korzystanie z produktów i usług bankowości elektronicznej jedynie w zakresie bankowości mobilnej.
\end{abstract}

Słowa kluczowe: czynniki społeczno-ekonomiczne, banki, klienci, produkty i usługi bankowe

\section{WSTĘP}

Bankowość elektroniczna, zwana w skrócie e-bankowością, której gwałtowny rozwój nastąpił w końcu XX wieku, znacząco zmieniła oblicze bankowości [Salehi, Alipour 2010, Ahmed, Phin 2016]. Klienci banków uzyskali możliwość korzystania z produktów i usług bankowych bez odwiedzania placówki bankowej, a instytucje uzyskały możliwość kontaktowania się z bankiem we własnej siedzibie, natomiast banki uzyskały nowy kanał sprzedaży produktów i usług [Jurkowski 2001]. Banki uzyskały możliwość rozwijania nowych strategii biznesowych opar- 
tych na szybkim docieraniu do klientów i proponowaniu oferty dostosowanej do ich indywidualnych potrzeb i oczekiwań, dzięki pozyskiwaniu o nich dokładnych i aktualnych informacji [Kisiel 2011].

W działaniach biznesowych banków szczególnie istotna jest znajomość oczekiwań klientów [Mazurkiewicz 2002]. Wielu badaczy stwierdziło, że na poziom korzystania z bankowości elektronicznej mają wpływ niektóre cechy społecznoekonomiczne, takie jak wiek, płeć, ale też miejsce zamieszkania, rodzaj aktywności zawodowej, wysokość dochodów [Munusamy i in. 2013, Karjaluoto i in. 2002].

Zadaniem badawczym jest określenie stopnia korzystania z produktów i usług bankowych dostarczanych kanałami elektronicznymi przez klientów charakteryzujących wybranymi cechami społeczno-ekonomicznymi. Celem badań było dostarczenie bankom i innym instytucjom finansowym poszerzonej wiedzy o klientach, stopniu korzystania z produktów i usług e-bankowości oraz postrzeganiu tej bankowości.

W artykule sformułowano następujące hipotezy badawcze:

H1. Cechy społeczno-ekonomiczne badanych klientów mają statystycznie istotny wpływ na poziom korzystania z produktów i usług bankowości elektronicznej.

H2. Na korzystanie z produktów i usług bankowości elektronicznej największy wpływ mają dochody klientów i rodzaj aktywności zawodowej.

\section{PRZEGLĄD LITERATURY}

Szerokie zastosowanie elektronicznych kanałów w bankowości ma bardzo szczególny wpływ na funkcjonowanie banków. Badania tej formy sprzedaży produktów i usług bankowych prowadzone były przez wielu naukowców na całym świecie i dotyczyły głównie:

- wpływu e-bankowości na efektywność instytucji bankowych [m.in. Gautam 2012, Simpson 2002, Siam 2006, Kolodinsky i in. 2004, Amedu 2005, Yunus, Akingbadei 2011, Josefowicz, Novarica 2011, Chau P. 2001, Malhotra, Singh 2000],

- wpływu e-bankowości na konkurencyjność banków [m.in. Shittu 2010, Tan, Teo 2000, Jun, Cai 2001, Pereira 2004, Josefowicz, Novarica 2011, Beckett i in. 2000, Bauer, Hein 2006],

- wpływu e-bankowości na ryzyko bankowe oraz bezpieczeństwo depozytów i operacji bankowych [m.in. Afolabi 2009, Malhotra, Singh 2000, Amedu 2005, Anguelov i in. 2004, Shafei, Mirani 2011, Khan, Karim 2010, Titrade i in. 2008, Mermod 2001, Obal 2005, Ndlovu, Sigola 2013].

W końcu XX wieku kanały elektroniczne w bankowości stały się powszechnym sposobem kontaktu z klientami. Była to znacząca innowacja. Wyzwaniem dla banków stało się zachęcenie klientów do przyjęcia tej nowej formy dostarczania produktów i usług bankowych. Powstało pytanie, jak na gotowość do przyjęcia 
bankowości elektronicznej wpływają płeć, wiek, poziom wykształcenia, wysokość dochodów, rodzaj aktywności zawodowej, miejsce zamieszkania klientów.

Otwartość na innowacje była przedmiotem badań nauk społecznych. Twórca teorii dyfuzji innowacji Everett M. Rogers [Rogers 2003] wskazał następujące cechy wczesnych naśladowców (ang. earlier adaptors), czyli osób, które łatwo i szybko przyjmują innowacje: lepsze (dłuższe) wykształcenie, wyższy status społeczny, wyższy stopień awansu społecznego, wyższa empatia, wyższa racjonalność i inteligencja. Właśnie spośród nich rekrutowali się klienci-pionierzy e-bankowości [Gerrard, Cunningham 2003, Kisiel 2011].

\section{BADANE CECHY SPOŁECZNO-EKONOMICZNE KLIENTÓW}

Płeć, według wielu badaczy, jest czynnikiem silnie wpływającym na akceptację i użytkowanie e-bankowości. Inni nie podzielają tego zdania. W tabeli 1. przedstawiono przegląd badań dotyczących płci, wieku, dochodów i statusu materialnego oraz wykształcenia i kompetencji informatycznych klientów jako czynników wpływającego na postrzegania e-bankowości.

Wiek klientów banków jako czynnik, który wpływa na przyjęcie e-bankowości oraz postrzeganie korzyści i zagrożeń stąd wynikających zdaniem wielu badaczy odgrywa bardzo ważną rolę. Istnieją jednak duże różnice w postrzeganiu roli tego czynnika. Na ogół badacze są zgodni, że wiek jest ujemnie skorelowany z gotowością do korzystania z e-bankowości oraz poziomem zadowolenia, im klienci starsi tym bardziej wyrażają obawy o bezpieczeństwo.

Poziom dochodów na ogół jest ważnym czynnikiem determinującym korzystanie z bankowości elektronicznej, jak i na korzystanie z usług bankowych w ogóle. Ogólnie badacze są zgodni, że im wyższy poziom dochodów, tym klienci częściej korzystają z elektronicznego dostępu do swojego rachunku oraz do przeprowadzania operacji finansowych.

Wykształcenie i poziom kompetencji informatycznych są czynnikami mającymi wpływ na przyjęcie e-bankowości, a także na zakres jej użytkowania. Badacze te dwie cechy traktują rozdzielnie, ale często je łączą. Na ogół badacze są zgodni, że czynnik ten pozytywnie wpływa na postrzeganie e-bankowości.

Eun-Ju i Jinkook stwierdzili, że wpływ czynników demograficznych konsumentów takich jak wiek i wykształcenie na przyjęcie nowej technologii, jest mniej silny niż potrzeba korzystania i wystarczające do tego umiejętności[Eun-Ju, Jinkook 2001]. Natomiast cechy demograficzne wpływają na postrzeganie użyteczności, łatwości obsługi, ryzyka i zagrożeń [Dhiraj, Deepti 2013].

Karjaluoto i współautorzy stwierdzili, że częściej korzystają z e-bankowości ludzie młodzi, mężczyźni, ludzie o wyższych dochodach oraz osoby z wyższym wykształceniem [Karjaluoto i in. 2002]. 
Munusamy i współautorzy [Munusamy i in. 2013] w badaniach na terenie Indii nie znaleźli związku między płcią, rasą, poziomem dochodów, wykształceniem i zawodem a przyjęciem bankowości internetowej, które zależy głównie od aktywności w Internecie. Awamleh i Fernandes oraz Seyal i Rahim stwierdzili, że na poziom satysfakcji z e-bankowości znacząco wpływały: wiek, wykształcenie, wysokość dochodów i wcześniejsze doświadczenia z Internetem [Awamleh, Fernandes 2005, Seyal, Rahim 2011].

Berger i Gensler stwierdzili, że wśród klientów e-bankowości w Niemczech przeważali ludzie młodsi, lepiej wykształceni, bardziej zadowoleni ze statusu zawodowego i dochodowego oraz mieszkający w miastach [Berger, Gensler 2007].

TABELA 1. Wpływ płci, wieku, dochodów i statusu materialnego oraz wykształcenia i kompetencji informatycznych klientów na postrzeganie bankowości internetowej

\begin{tabular}{|c|c|}
\hline Autor [rok] & Konkluzje z badań \\
\hline \multicolumn{2}{|r|}{ Płeć } \\
\hline $\begin{array}{l}\text { Kay [1992], Bell [1995] } \\
\text { Seyal i in. [2000] }\end{array}$ & $\begin{array}{l}\text { Mężczyźni mają bardziej pozytywne nastawienie do korzystania z kom- } \\
\text { puterów niż kobiety. }\end{array}$ \\
\hline Shashaani [1997] & $\begin{array}{l}\text { Mężczyźni są bardziej zainteresowani komputerami niż kobiety, co } \\
\text { przyczynia się do różnic w korzystaniu z internetu. }\end{array}$ \\
\hline $\begin{array}{l}\text { Gefen i Straub [1997] } \\
\text { Venkatesh i Morris [2000] }\end{array}$ & Mężczyźni łatwiej akceptują nowe technologie w miejscu pracy. \\
\hline Teo i Lim [2000], Teo [2001] & Mężczyźni częściej niż kobiety używają internetu. \\
\hline Ono i Zavodny [2002] & $\begin{array}{l}\text { Kobiety są znacznie mniej niż mężczyźni zainteresowane korzystaniem } \\
\text { z internetu w domu i w innych miejscach. }\end{array}$ \\
\hline Dahlana i in. [2002] & $\begin{array}{l}\text { W badaniach pracowników malezyjskiego banku stwierdzono, że męż- } \\
\text { czyźni są bardziej chętni do eksploracji danych niż kobiety. }\end{array}$ \\
\hline Ramayah i Jantan [2004] & $\begin{array}{l}\text { Mężczyźni więcej korzystają z Internetu w zakresie wysyłania wiado- } \\
\text { mości, przeglądania informacji i pobierania danych. }\end{array}$ \\
\hline $\begin{array}{l}\text { Venkatesh i Morris, [2000] } \\
\text { Chen i Wellman [2004] } \\
\text { MacGregor, Vrazalic [2005] } \\
\text { Laukkanen,Pasanen [2008] }\end{array}$ & $\begin{array}{l}\text { Mężczyźni są bardziej skłonni niż kobiety do przyjęcia bankowych e- } \\
\text { usług, ponieważ mężczyźni są bardziej niż kobiety zainteresowani tech- } \\
\text { nologią i bardziej obeznani z techniką. }\end{array}$ \\
\hline $\begin{array}{l}\text { Gefen i Straub [1997] } \\
\text { Wan i in. [2005] }\end{array}$ & $\begin{array}{l}\text { Płeć nie ma bezpośredniego wpływ na akceptację technologii w ogóle, } \\
\text { ale są różnice w akceptacji konkretnych technologii komputerowych, } \\
\text { mężczyźni są bardziej skłonni do przyjęcia nowej technologii, w tym } \\
\text { bankowości internetowej }\end{array}$ \\
\hline Gan i in. [2006] & $\begin{array}{l}\text { Płeć nie ma statystycznie istotnego wpływu na chęć korzystania z ban- } \\
\text { kowości elektronicznej. }\end{array}$ \\
\hline Invalli i in. [2011] & $\begin{array}{l}\text { Płeć nie odgrywa większej roli w akceptacji e-bankowości, przy czym } \\
\text { kobiety chętniej korzystają z ATM, mężczyźni z bankowości interneto- } \\
\text { wej. }\end{array}$ \\
\hline $\begin{array}{l}\text { Awamleh, Fernandes [2005] } \\
\text { Seyal, Rahim [2011] }\end{array}$ & $\begin{array}{l}\text { Nie ma różnic w satysfakcji klientów bankowości internetowej ze wzglę- } \\
\text { du na płeć. }\end{array}$ \\
\hline \multicolumn{2}{|r|}{ Wiek } \\
\hline Homburg i Giering [2001] & Wiek odgrywa negatywną rolę w ocenie jakości stron internetowych. \\
\hline
\end{tabular}


cd. tab. 1

\begin{tabular}{|c|c|}
\hline Autor [rok] & Konkluzje z badań \\
\hline Teo [2001] & Wiek jest kluczowym czynnikiem w przyjęciu internetu \\
\hline Mattila i in. [2003] & $\begin{array}{l}\text { Osoby powyżej 65. roku życia na ogół późno przysposabiają technolo- } \\
\text { gię. Klienci dorośli rezygnujący z bankowości internetowej jako powód } \\
\text { podawali niewystarczające szkolenie lub jego brak. Ponadto strony były } \\
\text { dla nich zbyt skomplikowane. }\end{array}$ \\
\hline Seyal i Rahim [2011] & $\begin{array}{l}\text { Wiek stanowi najważniejszy czynnik zadowolenia klientów z bankowo- } \\
\text { ści internetowej. }\end{array}$ \\
\hline Munusamy i in. [2013] & $\begin{array}{l}\text { Istnieje związek pomiędzy wiekiem a przyjęciem bankowości interne- } \\
\text { towej. Osoby w wieku do } 25 \text { lat są głównymi użytkownikami e-banko- } \\
\text { wości detalicznej i są bardziej skłonni do przyjmowania bankowości } \\
\text { internetowej. }\end{array}$ \\
\hline Saiti i in. [2015] & $\begin{array}{l}\text { Wraz z wiekiem zwiększa się używanie kart płatniczych, w tym także } \\
\text { kredytowych, zmniejsza się korzystanie z usług bankowych online. Ro- } \\
\text { śnie też zadowolenie z płatności elektronicznych. }\end{array}$ \\
\hline & Dochód i status materialny \\
\hline Teo [2001] & $\begin{array}{l}\text { Poziom dochodów jest istotnym czynnikiem wpływającym na korzysta- } \\
\text { nie z Internetu. }\end{array}$ \\
\hline $\begin{array}{l}\text { Al-Ashban,Burney's [2001] } \\
\text { Bucevska, Bucevska [2013] }\end{array}$ & $\begin{array}{l}\text { Klienci o wyższych zarobkach bardziej chętnie przyjmują bankowość } \\
\text { elektroniczną. }\end{array}$ \\
\hline Polasik [2012] & $\begin{array}{l}\text { Niski poziom dochodów wpływa negatywnie na skłonność do korzysta- } \\
\text { nia z bankowości elektronicznej }\end{array}$ \\
\hline Kolodinsky i in. [2004] & $\begin{array}{l}\text { Głównymi klientami bankowości elektronicznej w USA są osoby o wy- } \\
\text { sokich dochodach. Najważniejszymi determinantami korzystania z ban- } \\
\text { kowości elektronicznej są czynniki ekonomiczne, społeczne i demogra- } \\
\text { ficzne. }\end{array}$ \\
\hline Awamleh i Fernandes [2005] & $\begin{array}{l}\text { Dochód jest istotnym czynnikiem w postrzeganiu bezpieczeństwa trans- } \\
\text { akcji wpływającym na satysfakcję klientów. }\end{array}$ \\
\hline Gan i in. [2006] & $\begin{array}{l}\text { Klienci o niższych dochodach są bardziej skłonni do korzystania z e-ban- } \\
\text { kowości ze względu na niskie koszty. Klienci o wyższych dochodach oba- } \\
\text { wiają się e-bankowości ze względów bezpieczeństwa. }\end{array}$ \\
\hline \multicolumn{2}{|r|}{ Wykształcenie i kompetencje informatycznych } \\
\hline Kay [1992] & $\begin{array}{l}\text { Ludzie z wyższym wykształceniem mają większe predyspozycje w za- } \\
\text { kresie obsługi komputera. }\end{array}$ \\
\hline Mendoza i Toledo [1997] & $\begin{array}{l}\text { Istnieje znacząca zależność między wykształceniem wyższym i korzy- } \\
\text { staniem z Internetu w społeczeństwie chilijskim. }\end{array}$ \\
\hline $\begin{array}{l}\text { Al-Jabri i in. [1997] } \\
\text { Seyal i in. [2002] }\end{array}$ & $\begin{array}{l}\text { Wykształcenie ma pozytywne wpływ na postawy wobec techniki kom- } \\
\text { puterowej. }\end{array}$ \\
\hline Polatoglu i Ekin [2001], & $\begin{array}{l}\text { Na korzystanie z e-bankowości duży wpływ ma wiedza informatyczna } \\
\text { klientów. Większa wiedza na temat e-bankowości sprzyja korzystaniu } \\
\text { z niej. }\end{array}$ \\
\hline $\begin{array}{l}\text { Al-Ashban, Burney’s [2001] } \\
\text { Bucevska i Bucevska [2013] }\end{array}$ & $\begin{array}{l}\text { Lepiej wykształceni klienci bardziej chętnie przyjmują bankowość elek- } \\
\text { troniczną. }\end{array}$ \\
\hline $\begin{array}{l}\text { Black i in. [2001] } \\
\text { Ramayah i in. [2003] }\end{array}$ & $\begin{array}{l}\text { Wcześniejsze doświadczenia z internetem są jednym z najsilniejszych } \\
\text { czynników wpływających na przyjęcie e-bankowości. }\end{array}$ \\
\hline
\end{tabular}

Źródło: opracowanie własne na podstawie przeglądu literatury. 
Sohail i Shanmugham stwierdzili, że wiek i wiedza na temat bankowości elektronicznej, jak i konwencjonalnej, nie mają istotnego wpływu na przyjęcie e-bankowości w Malezji. Ważną rolę odgrywa dostępność internetu i odporność klientów na zmiany [Sohail, Shanmugham 2004].

Sathye, Liao i współautorzy oraz Tan i Teo stwierdzili, że typowe czynniki przyjęcia e-bankowości to złożoność, bezpieczeństwo, łatwość użycia, postrzegana użyteczność, wiek, płeć, wykształcenie, dochody i wcześniejsza znajomość komputera i Internetu [Sathye 1999, Liao i i in. 1999, Tan, Teo 2000].

Większość analizowanych badań została wykonana technikami ankietowymi przy zastosowaniu skali Likerta. 5-punktową skalę Likerta stosowali m.in.: [Ahmed, Phin 2016, Seyal, Rahim 2011], 6-punktową: [Floh, Treiblmaier 2006], zaś 7 punktową [Chan, Huang 2013]. Zazwyczaj były problemy ze zwrotem ankiet, np. Ahmed i Phin otrzymali tylko 120 ankiet na 300 [Ahmed, Phin 2016] Najczęściej wracało ich około 40\%. Lee i Lee uzyskali zwrot 1600 ankiet (ankieta on-line, wynagrodzenie za wypełnienie) [Lee, Lee 2001].

Narzędzia analizy statystycznej to najczęściej analiza regresji, test T [Floh, Treiblmaier 2006], ANOVA [Ahmed, Phin 2016], a także model logit [Bucevska, Bucevska 2013].

Analiza literaturowa daje szeroką wiedzę na temat stanu badań wpływu cech społeczno-ekonomicznych na przyjęcie i użytkowanie e-bankowości. Jednak nie ma jednoznacznych wyników. Oznacza to, że ten obszar badawczy jest trudny do zdiagnozowania i podjęcie go dziś, po ponad 20 lat po zaimplementowaniu e-bankowości jest uzasadnione.

\section{METODYKA BADAŃ}

Głównym przedmiotem badań było określenie wpływu cech społeczno-ekonomicznych klientów banków na poziom korzystania z produktów i usług bankowości elektronicznej.

Metoda badań. Badania przeprowadzono za pomocą ankiety on-line. Uzyskane wyniki opracowano według takich kryteriów, jak: płeć, wiek, wykształcenie, dochody i miejsce zamieszkania [Ostasiewicz 1999, Domański, Pruska 2000]. Zależności badano testem nieparametrycznym chi-kwadrat. Na początku przyjęto hipotezę zerową o braku zależności badanych cech jakościowych od wspomnianych kryteriów, po czym, gdy uzyskana wartość p nie była wyższa niż 0,05 hipotezę zerową odrzucano [Steczkowski, Zeliaś 1981]. Uzyskane wyniki przedstawiono w formie tabelarycznej. 
Próba badawcza. Badania ankietowe przeprowadzono na 557-osobowej próbie badawczej dobranej metodą doboru celowego [Wasilewska 2011]. Respondenci korzystali z bankowości elektronicznej i byli klientami jednego z 13 banków komercyjnych lub 36 banków spółdzielczych. Banki zostały wytypowane metodą doboru warstwowo-losowego (warstwami były typy banków; komercyjne spółdzielcze).

Respondenci pochodzili z terenu całego kraju. Udział respondentów z miast stanowił 74\%. Wiekowo dominowali ludzie młodzi, do 30 lat (60\%) i 31-40 lat (17\%). Udział kobiet wynosił 58\%, a mężczyzn - 42\%. Największy odsetek stanowili uczniowie i studenci (39\%) oraz pracownicy sfery budżetowej (20\%). Pozostałe grupy zawodowe nie przekraczały 10\% ogółu respondentów.

Procedura badań. Kwestionariusz ankiety zawierał 64 pytania dotyczące różnych oceny jakości oraz ważności produktów i usług bankowości elektronicznej zgrupowanych w trzech obszarach tematycznych:

- jakość i ceny produktów i usług (53 cechy),

- jakość obsługi klientów (11 cech),

- $\quad$ sprawność funkcjonowania systemu informatycznego banku (9 cech).

Oceny jakości i ważności produktów i usług respondenci dokonywali według 5-punktowej skali Likerta. Uzyskane wyniki poddano analizie matematyczno-statystycznej.

\section{WYNIKI BADAŃ}

Wpływ czynników społeczno-ekonomicznych klientów banków na korzystanie z bankowości internetowej przedstawiono w tabeli 2 .

Korzystanie respondentów ze wszystkich badanych produktów i usług bankowości internetowej i mobilnej wahało się w przedziale 6-8\% ogólnej ich liczby. Najczęściej deklarowały korzystanie z nich kobiety, osoby młode w wieku 18-30 lat, z wykształceniem wyższym, o dochodach do $1500 \mathrm{zł}$, pochodzące ze średnich i dużych miast, mające wiedzę i umiejętności informatyczne na poziomie dostatecznym i dobrym (tabela 2).

Najrzadziej korzystali z badanych produktów i usług bankowości internetowej i mobilnej mężczyźni, osoby w wieku 41-50 lat i powyżej 60 lat, z wykształceniem zasadniczym, o dochodach w przedziale 2501-3000 zł, pochodzący z miast do 50 tys. mieszkańców, dysponujące wiedzą i umiejętnościami informatycznymi na poziomie niedostatecznym i miernym (tabela 2). 
TABELA 2. Związek między wybranymi cechami społeczno-ekonomicznymi badanych respondentów a korzystaniem ze wszystkich badanych produktów i usług bankowości internetowej i mobilnej w Polsce (N=557)

\begin{tabular}{|c|c|c|c|c|c|c|c|}
\hline \multirow{2}{*}{\multicolumn{2}{|c|}{ Wyszczególnienie }} & \multicolumn{3}{|c|}{$\begin{array}{c}\text { Bankowość internetowa - wszystkie } \\
\text { badane produkty i usługi }\end{array}$} & \multicolumn{3}{|c|}{$\begin{array}{c}\text { Bankowość mobilna - wszystkie badane } \\
\text { produkty i usługi }\end{array}$} \\
\hline & & Nie korzysta & Korzysta & Ogółem & Nie korzysta & Korzysta & Ogółem \\
\hline \multirow{6}{*}{$\frac{\ddot{d}}{\tilde{L}}$} & \multirow{2}{*}{ Kobieta } & 298 & 21 & 319 & 292 & 23 & 315 \\
\hline & & $54,88 \%$ & $3,87 \%$ & $58,75 \%$ & $54,58 \%$ & $4,30 \%$ & $58,88 \%$ \\
\hline & \multirow{2}{*}{ Mężczyzna } & 206 & 18 & 224 & 201 & 19 & 220 \\
\hline & & $37,94 \%$ & $3,31 \%$ & $41,25 \%$ & $37,57 \%$ & $3,55 \%$ & $41,12 \%$ \\
\hline & \multirow{2}{*}{ Ogółem } & 504 & 39 & 543 & 493 & 42 & 535 \\
\hline & & $92,82 \%$ & $7,18 \%$ & $100,00 \%$ & $92,15 \%$ & $7,85 \%$ & $100,00 \%$ \\
\hline $\mathrm{X}$ & chi-kwadrat & & 0,42 & & & 0,32 & \\
\hline $\mathrm{X}$ & p-value & & 0,52 & & & 0,57 & \\
\hline \multirow{12}{*}{ 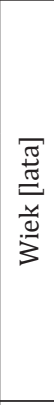 } & \multirow{2}{*}{$18-30$} & 300 & 27 & 327 & 295 & 26 & 321 \\
\hline & & $54,15 \%$ & $4,87 \%$ & $59,03 \%$ & $54,03 \%$ & $4,76 \%$ & $58,79 \%$ \\
\hline & \multirow{2}{*}{$31-40$} & 90 & 8 & 98 & 87 & 9 & 96 \\
\hline & & $16,25 \%$ & $1,44 \%$ & $17,69 \%$ & $15,93 \%$ & $1,65 \%$ & $17,58 \%$ \\
\hline & \multirow{2}{*}{$41-50$} & 49 & 0 & 49 & 47 & 2 & 49 \\
\hline & & $8,84 \%$ & $0,00 \%$ & $8,84 \%$ & $8,61 \%$ & $0,37 \%$ & $8,97 \%$ \\
\hline & \multirow{2}{*}{$51-60$} & 45 & 4 & 49 & 45 & 4 & 49 \\
\hline & & $8,12 \%$ & $0,72 \%$ & $8,84 \%$ & $8,24 \%$ & $0,73 \%$ & $8,97 \%$ \\
\hline & \multirow{2}{*}{$>60$} & 30 & 1 & 31 & 30 & 1 & 31 \\
\hline & & $5,42 \%$ & $0,18 \%$ & $5,60 \%$ & $5,49 \%$ & $0,18 \%$ & $5,68 \%$ \\
\hline & \multirow{2}{*}{ Ogółem } & 514 & 40 & 554 & 504 & 42 & 546 \\
\hline & & $92,78 \%$ & $7,22 \%$ & $100,00 \%$ & $92,31 \%$ & $7,69 \%$ & $100,00 \%$ \\
\hline $\mathrm{X}$ & chi-kwadrat & & 5,27 & & & 2,24 & \\
\hline $\mathrm{X}$ & p-value & & 0,26 & & & 0,69 & \\
\hline \multirow{8}{*}{ 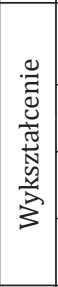 } & \multirow{2}{*}{ Zasadnicze } & 4 & 1 & 5 & 5 & 0 & 5 \\
\hline & & $0,73 \%$ & $0,18 \%$ & $0,91 \%$ & $0,92 \%$ & $0,00 \%$ & $0,92 \%$ \\
\hline & \multirow{2}{*}{ Średnie } & 176 & 10 & 186 & 165 & 16 & 181 \\
\hline & & $32,00 \%$ & $1,82 \%$ & $33,82 \%$ & $30,44 \%$ & $2,95 \%$ & $33,39 \%$ \\
\hline & \multirow{2}{*}{ Wyższe } & 331 & 28 & 359 & 330 & 26 & 356 \\
\hline & & $60,18 \%$ & $5,09 \%$ & $65,27 \%$ & $60,89 \%$ & $4,80 \%$ & $65,68 \%$ \\
\hline & \multirow{2}{*}{ Ogółem } & 511 & 39 & 550 & 500 & 42 & 542 \\
\hline & & $92,91 \%$ & $7,09 \%$ & $100,00 \%$ & $92,25 \%$ & $7,75 \%$ & $100,00 \%$ \\
\hline $\mathrm{X}$ & chi-kwadrat & & 2,37 & & & 0,82 & \\
\hline $\mathrm{X}$ & p-value & & 0,31 & & & 0,66 & \\
\hline \multirow{10}{*}{ 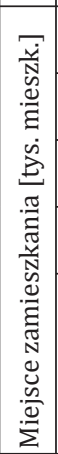 } & \multirow{2}{*}{ Wieś } & 136 & 10 & 146 & 133 & 9 & 142 \\
\hline & & $24,24 \%$ & $1,78 \%$ & $26,02 \%$ & $24,05 \%$ & $1,63 \%$ & $25,68 \%$ \\
\hline & \multirow{2}{*}{ Miasto $<50$} & 79 & 5 & 84 & 80 & 3 & 83 \\
\hline & & $14,08 \%$ & $0,89 \%$ & $14,97 \%$ & $14,47 \%$ & $0,54 \%$ & $15,01 \%$ \\
\hline & Miasto & 153 & 8 & 161 & 143 & 18 & 161 \\
\hline & $50-500$ & $27,27 \%$ & $1,43 \%$ & $28,70 \%$ & $25,86 \%$ & $3,25 \%$ & $29,11 \%$ \\
\hline & Mincto $>500$ & 154 & 16 & 170 & 155 & 12 & 167 \\
\hline & Miasto > 500 & $27,45 \%$ & $2,85 \%$ & $30,30 \%$ & $28,03 \%$ & $2,17 \%$ & $30,20 \%$ \\
\hline & & 522 & 39 & 561 & 511 & 42 & 553 \\
\hline & Ogółem & $93,05 \%$ & $6,95 \%$ & $100,00 \%$ & $92,41 \%$ & $7,59 \%$ & $100,00 \%$ \\
\hline $\mathrm{X}$ & chi-kwadrat & & 2,70 & & & 5,18 & \\
\hline $\mathrm{X}$ & p-value & & 0,44 & & & 0,16 & \\
\hline
\end{tabular}


cd. tab. 2

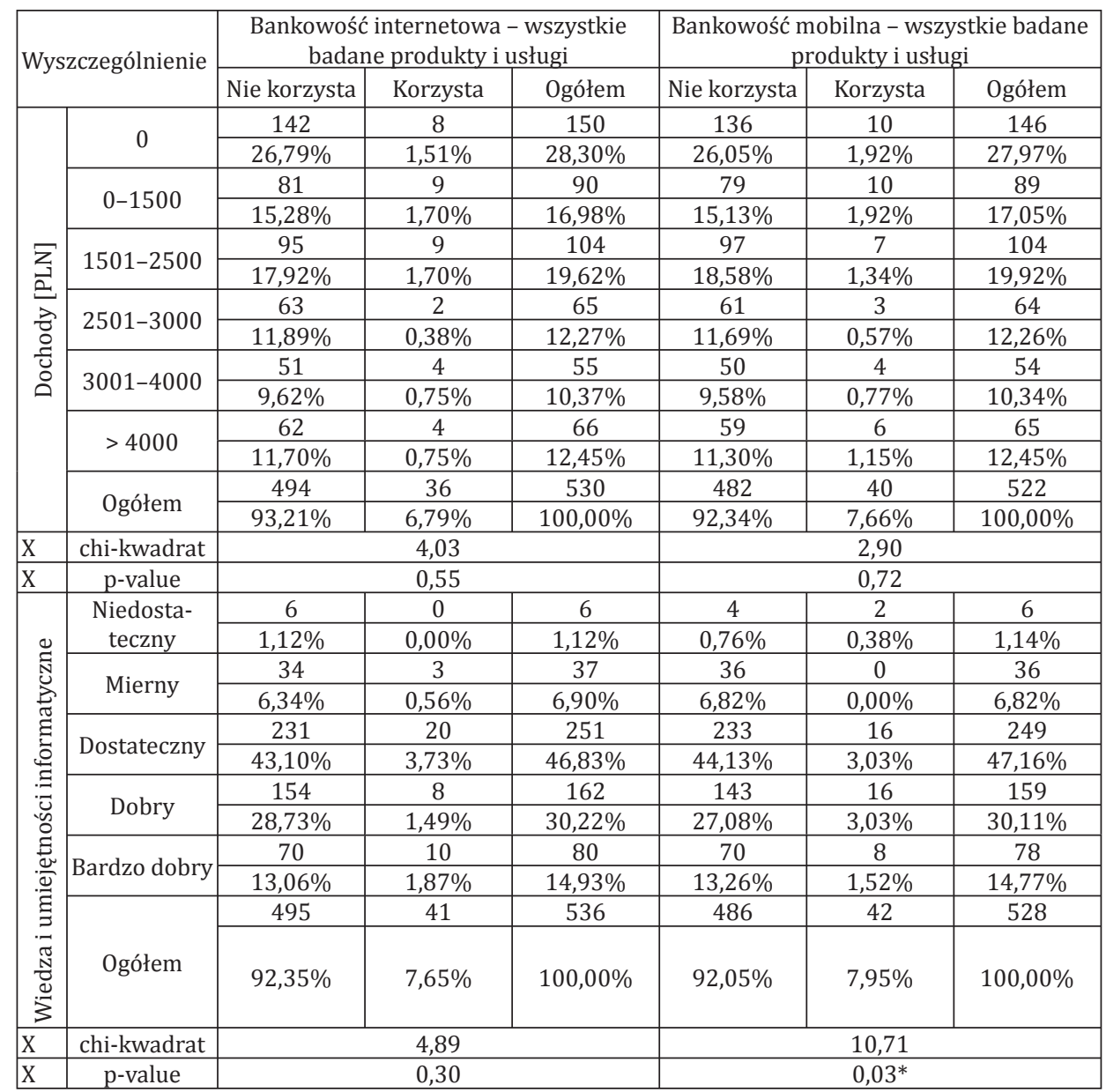

* statystycznie istotna zależność miedzy badanymi cechami jakościowymi przy p $\leq 0,05$. Odsetek respondentów w poszczególnych grupach obliczany był w stosunku do ogólnej liczby respondentów.

Źródło: badania własne.

Podsumowując należy jednak stwierdzić, że wpływ cech społeczno-ekonomicznych respondentów na korzystanie z wszystkich badanych produktów i usług bankowości internetowej i mobilnej był statystycznie nieistotny. Jedynym wyjątkiem była wiedza i umiejętności informatyczne respondentów, których wpływ na stopień korzystania z wszystkich badanych produktów i usług bankowości mobilnej był statystycznie istotny. 


\section{INTERPRETACJA WYNIKÓW}

Porównanie uzyskanych wyników z wynikami innych badaczy przedstawiono w tabeli 3.

Badane cechy społeczno-ekonomiczne respondentów: płeć, wiek, wykształcenie, dochody i miejsce zamieszkania nie mają wpływu na poziom korzystania z produktów i usług bankowości elektronicznej. Jedynie wiedza i umiejętności informatyczne respondentów mają statystycznie istotny wpływ na korzystanie z produktów i usług bankowości mobilnej. Na tej podstawie można stwierdzić, że pierwsza hipoteza badawcza została potwierdzona tylko częściowo, natomiast druga została zweryfikowana negatywnie.

Uzyskane wyniki badań nie są zgodne z większością prezentowanych badań. Przyczynami tego mogą być:

- Inne warunki wykonywanych badań. Większość prezentowanych badań dotyczyło e-bankowości w krajach rozwijających się, a także Europy Zachodniej i USA. Pewne nawyki, tradycje, a także wzory zachowań w tych krajach są inne.

- Różny czas badań. Najwięcej badań wykonanych było na przełomie wieków XX i XXI, czyli w początkowej fazie rozwoju bankowości elektronicznej. Obecnie po około 20 latach upowszechniania elektronicznych kanałów sprzedaży produktów i usług bankowych postrzeganie ich przez klientów znacznie się zmieniło.

\section{WNIOSKI}

1. Badane cechy społeczno-ekonomiczne respondentów, takie jak płeć, wiek, wykształcenie, dochody i miejsce zamieszkania nie miały wpływu na zakres korzystania z produktów i usług bankowości elektronicznej. Jedynym wyjątkiem była wiedza i umiejętności informatyczne respondentów, które miały statystycznie istotny wpływ na korzystanie z produktów i usług bankowości mobilnej, ale nie miały statystycznie istotnego wpływu na korzystanie z produktów i usług bankowości internetowej.

2. Pomimo braku związków między korzystaniem z bankowości elektronicznej a cechami społeczno-ekonomicznymi klientów banków, badania mają znaczenie praktyczne dla instytucji finansowych, bowiem wskazują, że rozwój kanałów elektronicznych jest drogą dotarcia do różnych grup klientów. Kanał ten pozwala na znaczne zwiększenie upowszechnienia produktów i usług bankowych dzięki pewnego rodzaju egalitaryzmowi w dostępie do nich.

3. Pomimo negatywnego zweryfikowania postawionych hipotez, istnieje uzasadnienie do kontynuacji badań w tym zakresie, bowiem wyniki wcześniejszych badań są niejednoznaczne. 


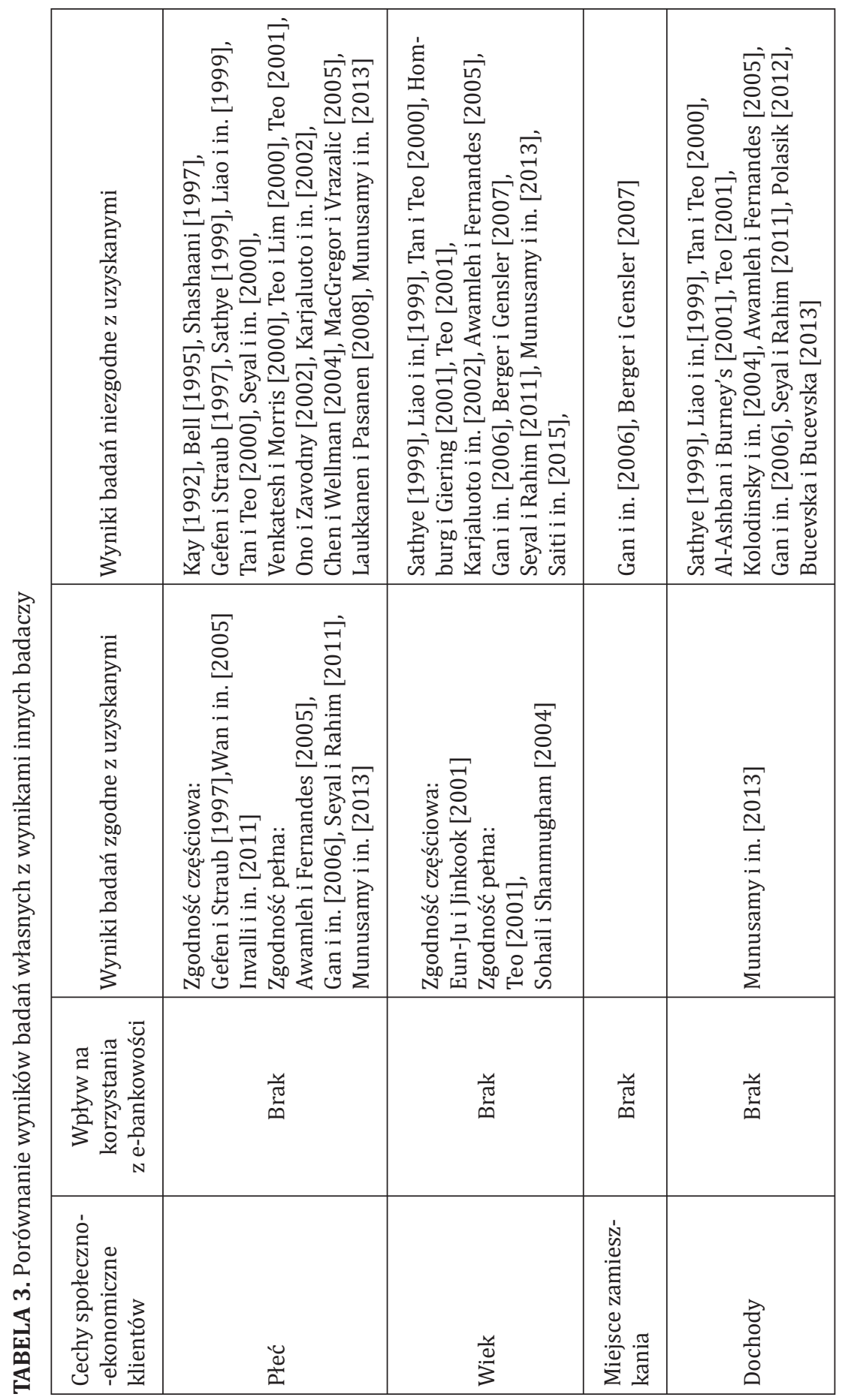


4. Inny dobór grupy badawczej w przypadku klientów banków jest trudny. Zatem w przyszłych badaniach należałoby zmniejszyć liczbę ocenianych produktów i usług, podzielić je na grupy i oceniać oddzielnie. Proponowane grupy produktów i usług to: rachunki osobiste, karty płatnicze, pożyczki i kredyty, produkty inwestycyjne oraz zaawansowane produkty inżynierii finansowej. Wyniki takich pogłębionych badań dadzą odpowiedź na pytanie, które produkty i usługi e-bankowości oferować poszczególnym grupom klientów oraz jak indywidualizować ofertę banków w tym zakresie.

\section{Spis literatury}

AHMED E.M., PHIN G. S., 2016: Factors Influencing the Adoption of Internet Banking in Malaysia. Journal of Internet Banking \& Commerce. Vol. 21 (1), s. 1-28.

AL-ASHBAN A. A., BURNEY, M. A., 2001: Customer Adoption of Tele-Banking Technology: The Case of Saudi Arabia. The International Journal of Bank Marketing. Vol. 19 (4/5) S. 191-200.

AL-JABRI M., AL-KHALDI A. M., 1997: Effects of User Characteristics on Computer Attitudes among Undergraduate Business Student. Journal of End-User Computing, Spring, s. $16-21$.

AWAMLEH R., FERNANDES C., 2005: Internet Banking: An Empirical Investigation into the Extent of Adoption by Banks and determinants of Customer Satisfaction in the UAE. Journal of Internet Banking and Commerce, Vol. 10 (1).

BAUER, HEIN 2006: The effect of heterogeneous risk on the early adoption of internet banking technologies. Journal of Banking and Finance. Vol. 30, s. 1713-1725.

BECKETT A., HEWER, P., HOWCROFT B. 2000: An Exposition of Consumer Behavior in the Financial Services Industry. The International Journal of Bank Marketing. Vol. 18 (1), s 15-26.

BELL M., 1995: The Impact of IT Education and Training, Computer Bulletin, BCS, Feb.

BERGER S. C., GENSLER S., 2007: Online Banking Customers: Insights from Germany. Journal of Internet Banking and Commerce. Vol. 12 (1), s. 1-6.

BLACK N.J., LOCKETT A., WINKLHOFER H., ENNEW C., 2001: The adoption of Internet Financial Services: A Qualitative Study. International Journal of Retail and Distribution Management. Vol. 29 (8), s. 390-398.

BUCEVSKA V., BUCEVSKA J., 2013: An empirical analysis of factors affecting the adoption of electronic banking in Macedonia: a logit model. Advances in Business-Related Scientific Research Journal. Vol. 4 (1), s. 27-37.

CHAN M. J., HUANG Y. H., 2013: Factors that affect consumer trust in online shopping in Taiwan. The Journal of Global Business Management. Dostępny na: http://www.jgbm. org/page/14\%20Mei-Jane\%20Chan.pdf (data uzyskania dostępu: 11.12.2016 r.).

CHAU P., 2001: Influence of computer attitude and self-efficacy on it usage behavior. Journal of End User Computting. Vol. 13 (1), s. 26-33. 
CHEN W. WELLMAN B., 2004: The global digital divide-Within and between countries. IT and Society. Vol. 1 (7), s. 39-45.

DAHLAN N., RAMAYAH T., KOAY A.H., 2002: Data Mining in the Banking Industry: An Exploratory Study. Proceedings of International Conference on Internet Economy and Business, Kuala Lumpur, Malaysia.

DHIRAJ J., DEEPTI D., 2013: Customer Perception about the Efficiency of E-Banking Services Offered by Commercial Banks: An Empirical Study. Prajnan. Vol. 42 (1), s. 65-81.

DOMAŃSKI Cz., PRUSKA K., 2000: Nieklasyczne metody statystyczne, PWE, Warszawa.

EUN-JU L., JINKOOK L., 2001: Consumer Adoption of Internet Banking: Need-Based and/or Skill Based? Marketing Management Journal. Vol. 11 (1), s. 101-113.

FLOH A., TREIBLMAIER H., 2006: What Keeps The E-Banking Customer Loyal? A Multigroup Analysis Of The Moderating Role Of Consumer Characteristics On E-Loyalty In The Financial Service Industry. Journal of Electronic Commerce Research. Vol. 7 (2).

GAN C., CLEMES M., LIMSOMBUNCHAI V., WENG A., 2006: A logit analysis of electronic banking in New Zealand. International Journal of Bank Marketing. Vol. 24 (6), s. 360-383.

GEFEN D., STRAUB D., 1997: Gender Difference in Perception and Adoption of E-mail: An Extension to the TAM:, MIS Quarterly, Vol. 21, s. 389-400.

GERRARD P., CUNNINGHAM J.B., 2003: The Diffusion of Internet Banking Among Singapore Consumers. International Journal of Bank Marketing. Vol. 21 (1), 16-28.

HOMBURG C., GIERING A., 2001: Personal Characteristics as Moderators of the Relationship Between Customer Satisfaction and Loyalty - an Empirical Analysis. Psychology and Marketing, Vol. 18 (1), s. 43-66.

INVALLI S., RAGHURAMA A., CHANDRAMMA M., 2011: Modeling the Adoption of Basic EBanking Services in Urban and Semi-Urban Regions in India. IUP Journal of Bank Management. Vol. 10 (3), s. 98-114.

JURKOWSKI A., 2001: Bankowość elektroniczna, Materiały i Studia NBP, nr 6, 16.

KARJALUOTO H., MATTILA M., PENTO T., 2002: Electronic Banking in Finland: Consumer Beliefs and Reactions to a New Delivery Channel. Journal of Financial Service Marketing Vol. 6 (4), 346-361.

KAY R.H., 1992: Understanding Gender Difference in Computer Attitudes. Journal of Research on Computing Education, Vol. 25 (2), s. 159-171.

KISIEL M., 2011: Internet a konkurencyjność banków w Polsce. Wyd. CeDeWu, Warszawa.

KOLODINSKY J.M., HOGARTH J.M., HILGERT M.A., 2004: The adoption of electronic banking technologies by US consumers. International Journal of Bank Marketing. Vol. 22, s. 238-259.

LAUKKANEN T., PASANEN, M 2008: Mobile banking innovators and early adopters: How they differ from other online users? Journal of Financial Services Marketing. Vol. 13 (2), s. 86-94.

LEE E. J.,i LEE J., 2001: Consumer adoption of internet banking: need-based and/or skill based? Marketing Management Journal. Spring. Vol. 11 (1), s.101-113. 
LIAO S., SHAO Y.P., WANG H., CHEN A., 1999: The Adoption of Virtual Banking: An Empirical Study. International Journal of Information Management Vol. 34 (4), s. 283-295.

LIAO Z., CHEUNG M.T., 2002: Internet-Based E-Banking and Consumer Attitudes: An Empirical Study. Information and Management. No. 39, s. 283-295.

MACGREGOR R, C., VRAZALIC, L., 2005: A basic model of electronic commerce adoption barriers: A study of regional businesses in Sweden and Australia. Journal of small business and enterprise development. Vol. 12 (4), s. 510-527.

MALHOTRA P, SINGH B., 2000:The Impact of Internet Banking on Bank Performance and Risk: The Indian Experience. Eurasian Journal of Business and Economics. Vol.2, s. 43-62.

MATTILA M., KARJALUOTO H., PENTO T., 2003: Internet banking adoption among adult customers: early majority or laggards? Journal of Services Marketing. Vol. 17 (5), s. 514-528.

MAZURKIEWICZ L., 2002: Marketing bankowy. Wyd. Difin, Warszawa.

MUNUSAMY J. CHELLIAH S., ANNAMALAH S., 2013: Demographic Factors and Adoption of Retail Internet Banking: An Experience in Malaysia. International Journal of Management \& Innovation. Vol. 5 (2), s. 34-48.

ONO H., ZAVODNY M., 2002: Gender and the Internet, SSE/EFI Working Paper Series in Economics and Finance, no. 495. Stockholm, Sweden.

OSTASIEWICZ W., 1999: Statystyczne metody analizy danych. Wyd. AE im. Oskara Langego we Wrocławiu, Wrocławiu.

PEREIRA M. J., 2004: Impacts of information systems and technology on productivity and competitiveness of the Portuguese banking sector: an empirical study. International Transactions In Operational Research, Vol. 11, s. 43-62.

POLASIK M., 2012: Bankowość elektroniczna. Istota-Stan-Perspektywy. Wyd. CeDeWu, Warszawa.

POLATOGLU V.N., EKIN S., 2001: An Empirical Investigation of the Turkish Consumers' Acceptance of Internet Banking Services. International Journal of Bank Marketing. Vol. 19 (4), s. 156-165.

RAMAYAH T., JANTAN M., 2004: Internet Usage among Malaysian Students: The Role of Demographic and Motivational Variables. The Journal of Management Awareness, Vol. 7 (2), s. 59-70.

RAMAYAH T., JANTAN M., NOOR M., NASEER M., RAZEK R.L., LING, K. P., 2003: Receptiveness of Internet Banking by Malaysian Consumers. Asian Academy of Management Journal. Vol. 8 (2), s. 1-29.

ROGERS E. M., 2003: Diffusion of innovations. Fifth edition. Wyd. Free PressNew York, London, Toronto, Sydney.

SAITI D., KISELICK M., JOSIMOVSKI S., 2015: Level of customer satisfaction from electronic banking services in the Polog region. Journal of Sustainable Development. Vol. 5 (13), s. $45-68$. 
SATHYE M., 1999: Adoption of Internet banking by Australian consumers: an empirical investigation. International Journal of Bank Marketing. Vol. 17 (7), s. 324-34.

SEYAL A. H., RAHIM M. Md., RAHMAN M.N., 2000: Computer Attitudes of Non-Computing Academics: A Study of Technical Colleges in Brunei Darussalam, Information and Management, Vol 37, s. 169-180.

SEYAL, A. H., RAHIM Md. M., 2011: Customer Satisfaction with Internet Banking in Brunei Darussalam: Evaluating the Role of Demographic Factors. e-Service Journal. Summer. Vol. 7 (3), s. 47-68.

SEYAL, A.H., RAHIM M. Md., RAHMAN M.N., 2002: A Study of Computer Attitudes of NonComputing Students of Technical Colleges in Brunei Darussalam. Journal of End-User Computing. April-June, s. 40-47.

SHASHAANI L., 1997: Gender Difference in Computer Attitudes and Use among College Students. Journal of Educational Research in Computing, Vol. 16(1), s. 27-51.

SOHAIL M., SHANMUGHAM B., 2004: E-banking and Customers' preferences in Malaysia: an empirical investigation. Information sciences, Informatics and Computer Science: an International Journal. Vol.150 (3-4), s. 207-217.

STECZKOWSKI J., ZELIAŚ A., 1981: Statystyczne metody analizy cech jakościowych. Wyd. PWE, Warszawa.

TAN M., TEO T., 2000: Factors Influencing the Adoption of Internet Banking. Journal of the Association for Information Systems. Vol. 1 (5), s. 1-42.

TEO T. S. H., 2001: Demographic and Motivational Variables associated with Internet Usage Activities. Internet Research: Electronic Networking Applications and Policy, Vol. 11 (2), s. 125-131.

TEO T.S.H., LIM V.K.G., 2000: Gender differences in Internet Usage and Task Preferences. Behaviour and Information Technology, Vol. 19 (4), s. 283-295.

VENKATESH V., MORRIS M. G., 2000: Why Don't Men Stop to Ask for Directions, Gender, Social Influence and their Role in Technology Acceptance and Usage Behavior, MIS Quarterly, Vol. 24 (1), s. 115-139.

WASILEWSKA E., 2011: Statystyka opisowa od podstaw. Podręcznik z zadaniami. Wydawnictwo SGGW, Warszawa.

\title{
THE IMPACT OF SOCIO-ECONOMIC CHARACTERISTICS ON THE LEVEL OF CUSTOMER USE OF THE PRODUCTS AND SERVICES OF ELECTRONIC BANKING
}

\begin{abstract}
The aim of this work is to show the impact of socio-economic characteristics (age, place of residence, education, professional activity, income level, computer knowledge) of the customer on the use of products and services of the electronic banking. The work consists of two parts. The first part presents the results of previous studies on using bank e-services by theirs customers. The
\end{abstract}


second part describes the author's own studies and their results. The impact of demographic factors on the level of the use of these banking e-services was determined by using the chi-squared test. The research results show that only the knowledge and IT skills of the respondents impact the use of electronic banking products and services in the field of mobile banking.

Key words: socio-economic characteristics, banks, customers, bank products and services 